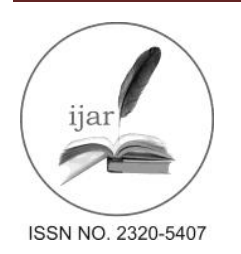

Journal homepage: http://www.journalijar.com
Journal DOI: 10.21474/IJAR01

RESEARCH ARTICLE

\title{
EFFECT OF FEED AND FERTILIZERS ON THE GROWTH AND BODY COMPOSITION OF AIR BREATHING FISHES CHANNA STRIATA AND PANGASIUS HYPOPHTHALMUS FRY.
}

INTERNATIONAL JOURNAL

OF ADVANCED RESEARCH

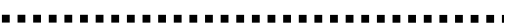

Panchakshari .V, Krishna .P.V, K., Prabhavathi. K. and K. Bhanu Prakash.

Department of Zoology \& Aquaculture, Acharya Nagarjuna University, Nagarjuna Nagar - 522 510, A.P., India

Manuscript Info

Manuscript History:

Received: 12 May 2016

Final Accepted: 19 June 2016

Published Online: July 2016

Key words:

Meat composition, Channa striata,

Pangasius hypophthalmus.

*Corresponding Author

P. V. Krishna

\begin{abstract}
Experiments were conducted to evaluate the response of five treatments to observe the growth performance and meat composition of Channa striata and Pangasius hypophthalmus advanced fry for the period of 60 days. Composition of nitrogen in different experiments treatment with different combinations of supplementary feed. The pond was supplemented with $0.2 \mathrm{~g}$ $\mathrm{N} / 100 \mathrm{~g}$ body weight fertilizers and supplementary feed, the source of which are different. The treatment was cow dung, pig dung, nitrophos, supplementary feed and probiotics in 5 treatments. The highest fish production was recorded in treatment of supplementary with probiotics. Among the species channa goes to better result compare with the pangus. The present study revealed that there is a significant difference $(\mathrm{P}<0.05)$ between body composition of the studied fish species. Moreover, variations also exist between the fishes of the same species for all the constituents.
\end{abstract}

Copy Right, IJAR, 2013,. All rights reserved.

\section{Introduction:-}

The increase in human population that led to shortage of animal protein sources all over the world has directed the attention to fish as rapid and healthy compensatory source of good quality animal protein. Fishes are quite different from the other animal food sources, because they provide calories with high quality proteins, which contain all essential amino acids in easily digestible form. So, they are beneficial nutrition sources. Good quality and adequate nutrition plays a very important role in the expression of mental, physical, and intellectual qualities in humans. They have the ability to reduce blood lipid level, particularly serum triglycerides (Boberg, 1990) and also have a good source for human nutrition due to their therapeutic role in reducing certain cardiovascular disorders (Stickney and Hardy, 1989; Ahmed, 2011). The per capita availability of fish in India is now $9.5 \mathrm{~kg}$ with $56 \%$ of Indians considered fish eaters. It was estimated that by 2010, India requirements for fish would be around 10 million tons (Gopakumar, 2003). Channa striata is the highly prized freshwater, air-breathing fish and hence has a good culture potential. The fish is well known for its taste, high nutritive value, recuperative and medicinal qualities. It has fine white flesh without any intra-muscular bones and is believed to contain recuperative and strength-giving substances, and it is therefore, especially given to elder people. Yaakob and Ali (1992) also noted the importance of snakehead for hastening the healing of wounds and internal injuries due to the presence of certain fatty acids such as prostaglandin and thrombosis. Pangasius hypothaamus is popularly known as panguss belonging to the family pangasidae. This species is highly tolerant to salinity, dissolved oxygen, temperature or even pollution. It is omnivorus, feeding on a variety of organism. It is a fast growing and widely cultured species in the inland sector, mainly in the states of Andhra Pradesh and West Bengal in India. The fillets are characterised by white or pale pink coloured flesh, absence of fishy odour, small bones, delicate and firm texture. These attributes help in the preparation of value added products, which can considerably enhance the market acceptability. The better production fish culture needs use of organic fertilizers and optimum utilization of naturally available food through 
composite fish culture (Jingram 1997). A shorter cycle of plankton production can be possible through the use of organic manure in comparison to the application of inorganic fertilizers. The addition of manure influence the relative abundance of plankton density and their community structure in pond aquaculture system.

Feed is the single most important factor in intensive aquaculture, sometimes it costs more than $50 \%$ of the total operational cost (Krishna, 2006). Due to the increasing demand for fish feed and the price of feed ingredients, the production cost also dramatically increases that ultimately results in decrease of the profit from aquaculture. Efforts have been employed to minimize the fish production cost by different approaches. Compensatory or catch-up growth offers the possibility of improving the growth rates of fish by a careful choice of feeding schedules in which periods of feed deprivation are followed by periods of satiation feeding (Ali et al. 2003). Reduced feed intake in fish, however, need not be the result of limited feed supply, but may depend on external environmental factors prohibiting the fish from taking feed (Krishna,2005) which would decrease the fish production cost. The mechanism of this phenomenon is poorly understood (Zhu et al. 2005).

Success of any fish culture largely depends on a continual supply of food through natural (fertilization) and supplementary feed. The combination of two to three species may ensure maximum utilization of available natural and food in water bodies because of their different feeding habits. The present study was goes to Channa striata along with pangus ( $P$. hypophthalmus) by using fertilization and supplementary feeding in polyculture system. Supplementary feeding in fertilized ponds resulted in significantly higher growth rates and greater yields than fertilization alone (Green, 1992; Diana et al, 1994).Composition of the body is a good indicator for the physiological condition of a fish but it is relatively time consuming process. Proximate body composition is the analysis of carbohydrates, proteins, lipids, moisture and ash contents of fish. The lower percentage of water, greater lipids, protein contents, and higher energy density present in the fish (Dempson et al., 2004). An important contribution have been made on the study of the body composition and their caloric values of different freshwater fishes by following workers; Ali et al., (2003); Peyami et al., (2006); Albrektsen et al., (2006); Asdari et al., (2011). Body composition of different types of fishes was also explained by : Dawson and Grimm, (1980); Shearer, (1984); Salam and Davies, (1994); Singh et al., (2006); Grayton and Beamish, (1997); Jonsson and Jonsson, (1998); Dempson, et al., (2004); Khan and Abidi, (2010); Ahmed, (2011) ;Noor Khan et al., (2011); Ullah et al., (2014) and Lopamudra et al., (2015) Ali et al., (2016). The present study was carried for the body composition of channa and pangus using the body composition as an index of growth studies in a cultured pond located in Eluru, area. Analysis of body composition were done at department of Zoology and Aquaculture, Acharya Nagarjuna University. Andhra Pradesh, India.

\section{Materials and Methods:-}

The experiment was conducted at the fish farm Eluru, West Godavari distict, Andhra Pradesh. During the month of August and September of 2015. The ponds were prepared the following standard management practices (Jhingram, 1997). The advanced fry of channa (Channa striata) average weight $1.13 \mathrm{~g} \pm 0.09$ and pangus Pangasius hypothalmus of average weight $1.09 \mathrm{~g} \pm 0.08$ were purchased from the private fish farm at Eluru. Each species was separately held in oxygenated polythene bags were placed near the experimental ponds and filled with fresh pond water. Each species of fish graded, counted, weighted, and immediately distributed into the ponds. The fry was transported to the experimental fish with oxygenated polythene bags. The fry was stocked at a stocking density of 20 Nos/m2 (1.98 lak/ha).

Each pond was stocked in ratio 2: 3 of channa and pangus with polyculture systems five feeding treatments are (Table 1) determined the body composition of culture organisms. The system consisted of ten one hectare earthen ponds consists water depth about 1.5-2.0 m located at the experimental station. All experimental ponds were drained and sundried for 15 days. Nylon screen enclosures were installed on the water inlet and outlet pipes of each pond to prevent escape and entry of unwanted fishes. All ponds were fertilized using a standard fertilization program (Hepher, 1963) for initiate and promote natural organism to grow. Fertilization was done on weekly basis while feeding was done on daily basis. The supplementary feed was formulated for treatment T3, T4 and T5 having 28.5\% crude protein by following Pearson method (Rath, 2000) including fish meal, rice polish, sunflower meal, vitamin and minerals premix. After one-month interval, on the basis of wet fish body weights, amount of organic and inorganic fertilizer and supplementary feed to be added in fish ponds were determined for each treatment. Water quality in the experimental ponds was monitored (APHA,1998) every one week to maintain water quality except D.O. The D.O was observed every day. 
Table 1: Composition of Nitrogen in different experimental ponds.

\begin{tabular}{|c|c|c|}
\hline Treatment & Source of Nitrogen & Nitrogen \% \\
\hline Treatment -1 & Cow dung and Pig dung & $50 \%+50 \%$ \\
\hline Treatment -2 & Cow dung and Nitrophos & $50 \%+50 \%$ \\
\hline Treatment -3 & Cow dung and Supplementary feed & $50 \%+50 \%$ \\
\hline Treatment -4 & Cow dung, Nitrophos and supplementary feed & $25 \%+25 \%+50 \%$ \\
\hline Treatment -5 & Cow dung, Nitrophos, \\
& supplementary feed and probiotics & $25 \%+25 \%+50 \%$ \\
\hline
\end{tabular}

At the final harvest, the meat samples of fishes from culture ponds were examined for the proximate composition of fish species in terms of moisture, crude protein, total fats, total ash and carbohydrates to study the effect of fertilization, supplementary feed and supplementary feed along with probiotic (Amruth fish) as feed probioticsPvt , on the meat composition of channa and pangus by using Association of Official Analytical Chemist (AOAC,1995) standard techniques. For this purpose five fishes were randomly selected from each pond. Three meat samples were taken from each specimen. Head, viscera, bones, fins, scales and tails of these fishes were removed and only their flesh was used for analysis. The detailed procedure for each analysis is given as the following.

\section{Fish Growth Parameters:}

\section{Specific Growth Rate:}

In (Final body weight) - In (Initial body weight)

SGR:

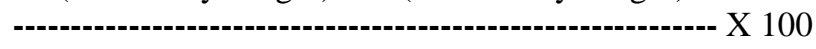

Time duration (days)

\begin{tabular}{|c|c|}
\hline \multirow{2}{*}{ Survival rate: } & No of fish harvested \\
\hline & No of fish stocked \\
\hline & Final weight - Initial body weight \\
\hline
\end{tabular}

\section{Moisture:-}

One gram of meat samples were taken in a weighted Petri dish $\left(\mathrm{W}_{1}\right)$ and placed it in the oven at $60^{\circ} \mathrm{C}$ for 12 hours or until dried. The dried samples were transferred to desiccators for 5 minutes and weighted. The samples were again kept in oven for one to two hours until constant weight $\left(\mathrm{W}_{2}\right)$ was obtained. The loss in weight was recorded as moisture.

$$
\text { Moisture (\%) }=\frac{\mathrm{W}_{1}-\mathrm{W}_{2}}{-------}
$$

Where, $\mathrm{W}_{1}=$ weight of Petri dish + sample before drying; $\mathrm{W}_{2}=$ weight of Petri dish + sample after drying; $\mathrm{W}_{3}=$ weight of the sample; Dry matter percentage was calculated by the following; Dry matter $(\%)=100$ - moisture (\%)

\section{Crude protein:-}

Crude protein of the meat samples were analyzed by using micro Kjeldahl's method. A digestion mixture of $\mathrm{K}_{2} \mathrm{SO}_{4}$ and $\mathrm{CuSO}_{4}$ in proportion of 9:7 was prepared. One gram of dried sample and a $5 \mathrm{~g}$ of digestion mixture were weighed into Kjeldahl's flask. $30 \mathrm{ml}$ of concentrated $\mathrm{H}_{2} \mathrm{SO}_{4}$ was added to it. The mixture was boiled at low temperature and then vigorously at high temperature until the mixture turned transparent clear greenish. Digested material was cooled down and volume was made up to $250 \mathrm{ml}$ with distilled water. $10 \mathrm{ml}$ of this diluted volume and $10 \mathrm{ml}$ of $40 \% \mathrm{NaOH}$ were put in apparatus and distilled with steam. Ammonia liberated was collected in 10ml of $2 \%$ boric acid solution with a drop of methyl red indicator. Ammonia was collected for about 2 minutes after the color of indicator changed from pink to golden yellow. Then ammonia in boric acid solution was titrated against $(0.1 \mathrm{~N})$ $\mathrm{H}_{2} \mathrm{SO}_{4}$, volume of $\mathrm{H}_{2} \mathrm{SO}_{4}$ used was noted and Nitrogen (\%) calculated as under: 


$\operatorname{Nitrogen~}(\%)=\frac{\text { Volume of } \mathrm{H}_{2} \mathrm{SO}_{4} \text { used X Normality of } \mathrm{H}_{2} \mathrm{SO}_{4} \text { X } 0.014 \text { X } 250}{\text { Weight of the sample X } 10}$

Where;

$0.014=$ Standard volume of $(0.1 \mathrm{~N}) \mathrm{H}_{2} \mathrm{SO}_{4}$ used to neutralize $1 \mathrm{ml}$ of ammonia.

$250=$ Dilution of the digested mixture

$100=$ for percentage of $\mathrm{N} 2$.

$10=$ Volume of the digested and diluted sample used.

Crude protein in sample was calculated by following formula.

Crude protein $(\%)=\% \mathrm{~N} 2 \times 6.25$

Whereby, $\quad 6.25=$ Assumed factor for equation of $\mathrm{N} 2 \%$ to crude protein.

Total fats:-

Total fat contents of meat samples were determined following petroleum ether extraction method through the Soxtec HT2 1045 system. The sample was placed in the Soxtec thimble, which was attached to the adapter. A defatted cotton wool was plugged on the top of the sample. The thimble was inserted into the condenser. The heating plate handle was pressed down and already weighted extraction cup, having petroleum ether up to 50-70 ml inserted in it. The main switch was switched on and cold water tap was turned on. The extraction cup was then clamped into the condenser. Extraction mode knob was moved to "Boiling" position for 15 minutes. The thimble was then immersed in the solvent. The material was boiled with thimble immersed in it. It was made sure that the condenser valves were opened. The extraction mode knobs were moved to the "Rinsing" position for 30 minutes. Thimble was then hanged above the solvent surface. After rinsing, the condenser valves were closed by turning a quarter turn. The extraction cup was released and the condenser valves were opened. Later on the "Main" switch was switched off and cold water tap was turned off. Extraction cup with trace amount of petroleum ether solvent and fat was placed in oven for drying. After drying, extraction cup was transferred to desiccators for 5 minutes and again weighted. Total fat percentage of the sample was calculated by following formula:

Where, $\quad \mathrm{W}_{1}=$ Weight of empty extraction cup

$$
\text { Total Fats }(\%)=\frac{\mathrm{W}_{2}-\mathrm{W}_{1} \times 100}{- \text { Weight of sample }}
$$

$\mathrm{W}_{2}=$ Weight of extraction cup with fat after Evaporation.

\section{Total ash:}

The total ash was determined by burning $2 \mathrm{~g}$ of dried fish tissue in a pre-weighed China dish and then samples were placed in a muffle furnace for ignition at $550-600^{\circ} \mathrm{C}$ till residue was obtained after $4-5$ hours. Then the samples residue were placed in desiccators to cool and then weight was recorded. Percentage of ash was obtained by using the following formula:

Total ash $(\%)=\mathrm{Wt}$. of ash $\times 100 \mathrm{Wt}$. of sample

Carbohydrates:- The total carbohydrates were determined as follows: 100- (Moisture + Crude protein + Total fats + Total Ash).

\section{Results and Discussion:-}

The growth performance of channa and pangus fry fed on different treatments were given (Table 2 and3). Final weight gain percentage was maximum recorded in the treatment 5 in the both fishes. Survival rate and specific growth rate also observed in similar trend in the treatment 5 in both fishes. The 60 days study period water quality parameters was observed i.e. temperature ranged from $28-35^{\circ} \mathrm{C}$, pH values was 7.2 to 8.1 , Total alkalinity 86 to $115 \mathrm{mg} / \mathrm{l}$, Total hardness 94 to $152 \mathrm{mg} / \mathrm{l}$ and DO was 4.9 to $5.8 \mathrm{mg} / \mathrm{l}$. The water quality parameters exert a significant influence on the growth, survival, and production of the organisms. In the present experiment, the water quality parameters are within permissible ranges and within the acceptable limits. Growth of fry and fingerlings to greater extent was depended on the quality of food (Krishna, 2006). Rearing of fry in nurseries is an important and crucial step in the fish culture and the adverse conditions were improper management may leads to severe damage and consequences resulting in mortality fry to some extent (Krishna, 2006). 
Table 2:- Growth performance of Channa observed in different treatments.

\begin{tabular}{|l|c|c|c|c|c|}
\hline \multirow{2}{*}{ Growth Parameters } & \multicolumn{4}{|c|}{ Treatments } \\
\cline { 2 - 5 } & T1 & T2 & T3 & T4 & T5 \\
\hline Initial weight (g) & 1.15 & 1.12 & 1.13 & 1.12 & 1.12 \\
\hline Final Weight(g) & 24.5 & 24.2 & 31.5 & 34.6 & 40.5 \\
\hline Weight gain\% & 2030 & 2060 & 2687 & 2989 & 3516 \\
\hline Survival\% & 64.5 & 65.5 & 75.6 & 78.5 & 83.4 \\
\hline SGR & 1.93 & 2.45 & 2.68 & 2.86 & 2.96 \\
\hline
\end{tabular}

Table 3:- Growth performance of Pangus observed in different treatments

\begin{tabular}{|l|c|c|c|c|c|}
\hline \multirow{2}{*}{ Growth Parameters } & \multicolumn{4}{|c|}{ Treatments } \\
\cline { 2 - 5 } & T1 & T2 & T3 & T4 & T5 \\
\hline Initial weight (g) & 1.10 & 1.09 & 1.08 & 1.10 & 1.1 \\
\hline Final Weight(g) & 26.4 & 27.2 & 32.4 & 35.8 & 39.8 \\
\hline Weight gain\% & 2300 & 2395 & 2900 & 3154 & 3518 \\
\hline Survival\% & 67.4 & 68.5 & 76.3 & 78.2 & 89.3 \\
\hline SGR & 1.95 & 2.25 & 2.78 & 2.95 & 3.12 \\
\hline
\end{tabular}

Table 4: Comparison of mean on the proximate analysis of two fish species under different treatments

\begin{tabular}{|c|c|c|c|c|c|c|}
\hline \multirow[t]{2}{*}{ Fish Species } & \multicolumn{5}{|c|}{ Treatments } & \multirow[t]{2}{*}{ Mean } \\
\hline & T1 & $\mathbf{T 2}$ & T3 & T4 & T5 & \\
\hline & \multicolumn{6}{|c|}{ Moisture (\%) } \\
\hline Channa & 77.4 & 78.4 & 79.56 & 76.82 & 77.9 & 78.01 \\
\hline Pangus & 75.4 & 76.4 & 76.4 & 76.2 & 76.2 & 76.12 \\
\hline \multirow[t]{2}{*}{ Mean } & 76.4 & 77.4 & 77.9 & 76.51 & 77.05 & 77.05 \\
\hline & \multicolumn{6}{|c|}{ Crude Protein (\%) } \\
\hline Channa & 17.86 & 17.52 & 16.61 & 16.94 & 19.87 & 17.76 \\
\hline Pangus & 16.45 & 16.38 & 15.95 & 17.25 & 18.75 & 16.95 \\
\hline \multirow[t]{2}{*}{ Mean } & 17.15 & 16.95 & 16.28 & 17.09 & 19.31 & 17.35 \\
\hline & \multicolumn{6}{|c|}{ Total fats (\%) } \\
\hline Channa & 1.52 & 1.65 & 1.78 & 2.32 & 2.52 & 1.95 \\
\hline Pangus & 1.06 & 1.35 & 1.54 & 1.94 & 1.95 & 1.56 \\
\hline \multirow[t]{2}{*}{ Mean } & 1.29 & 1.5 & 1.66 & 2.13 & 2.23 & 1.76 \\
\hline & \multicolumn{6}{|c|}{ Total ash (\%) } \\
\hline Channa & 1.50 & 1.55 & 1.53 & 1.83 & 1.94 & 1.67 \\
\hline Pangus & 1.32 & 1.30 & 1.32 & 1.82 & 1.77 & 1.50 \\
\hline \multirow[t]{2}{*}{ Mean } & 1.41 & 1.42 & 1.42 & 1.85 & 1.85 & 1.59 \\
\hline & \multicolumn{6}{|c|}{ Carbohydrates (\%) } \\
\hline Channa & 1.53 & 1.55 & 1.62 & 1.85 & 1.95 & 1.7 \\
\hline Pangus & 1.30 & 1.25 & 1.46 & 1.86 & 1.46 & 1.46 \\
\hline Mean & 1.41 & 1.4 & 1.54 & 1.85 & 1.70 & 1.58 \\
\hline
\end{tabular}

Feed is the major concern for intensive aquaculture and the commercial feeds are very costly and also expected feed conversion efficiency is not always achieved. In this circumstance, proper utilization of these feeds can only improve the benefit level of fish farmers by reducing the feed costs. One such benefit could be achieved by applying mixed feeding schedules. On the other hand, if the feeds are properly utilized, the possibility of water quality deterioration is less which ultimately will help to increase the production of fish. The results of the present study revealed that an increase in the level of incorporated probiotics with supplementary feed resulted in significant effect on the flesh crude protein content in the air breathing fish channa, and pangus (cat fish). Same continued total fat, total ash and carbohydrates also. Changes in body composition in relation to type of food ingested are a common phenomenon in all species of fish (Papoutsoglou and Paparaskeva- Papouslogdou, 1978; Schwarz et al., 1984; Desilva and Gunasekera, 1989). The quantity and quality of supplementary feed have a pronounced effect in growth rate, feed conversion efficiency and proximate composition of fish (Jena et al., 2002). The proximate composition of fish meat of between the two species showed that maximum moisture content were observed in channa in $\mathrm{T} 1$ and $\mathrm{T} 3$ 
(79.56 \%) and minimum were noticed in T4 and T5 (76.2\%) in pangus (Table 4). The main constituent of muscle of the fish is moisture, which play an important role in their metabolism. The water content of fish is varied within the limited range in various species (Afser and Ali, 1981). The body moisture undergoes cyclic changes along with fattening of the body (Afser, 1992; Peyami et al., 2006).

In body composition of the fish are an important attribute which affected by pond ecosystems, fertilization (Hassan, 1996) feed ingredients (Javed et al., 1995), probiotics (Krishna et al., 2009) and feeding rates (Hassan and Mocintosh, 1993). The proximate composition of fish meat of two species shows that the crude protein content were observed maximum in channa in T5 $(19.87 \%)$ and minimum in T3 $(15.95 \%)$ in pangus. The protein contributed from the supplementary feed and natural diet combination might be efficiently utilized by the fish for synthesis of tissue protein, leaving the scope for diversion to energy production through domination. Hassan (1996) and Javed et al., (1995) confirmed these results by reporting that meat quality is affected by fertilization and supplementary feed. Hassan et al., (2000) reported that significant difference in carcass composition of fish was observed between the treatments for various treatments. Krishna et al., (2015) reported that the body composition of fish is influenced by the chemical composition of the diet. In the present study compare with among diets probiotic corporate $\mathrm{T}-5$ recorded better growth and survival of both channa and pangus. Similar results were observed by Murthy and Naik, (2000); Kumar et al., (2006); Lopamudra et al., (2015).

The total fat, the percentage goes maximum in T5 $(2.52 \%)$ and minimum in T1 $(1.06 \%)$. Channa goes to maximum percentage of total ash in T5 (1.94\%) and minimum total ash (1.50) in T1. The inclusion of supplementary feed along with probiotics the crude protein, crude lipid and carbohydrates percentage increases compare with other diets. Among the species, channa goes to better results in case of crude protein (mean value 17.76\%) and total fats (mean value $1.95 \%$ ). These results are supported by (Keshavanath et al., 2006). Further, Hepher (1963) stated that natural food organisms contain low energy, while protein is in excess. Therefore, fish consuming only natural food have minimal fat and maximum protein accumulation in their body. Our results are also similar that crude protein content in treatments T1, T2 and total fat content in treatment T1, T2. Information regarding different fish contents such as protein, fats, carbohydrates and other nutrients and how they vary in different fish species used is very important for the consumers. This information helps them to select the most suitable fish species because of having elevated protein contents. It is also facilitates the consumer to select fish of optimum size and suitable for consumption.

The study clearly indicates that a combination of live food (natural food through fertilization) and supplementary feed provides a better nutritional profile in culture species to support quality and quantity fish production. Addition of probiotics goes to increase the production better feed management strategy by less pollution load. The natural and supplementary feeds solved the problems of inadequate nutrient supply encountered through the addition of the probiotics. This will provide better production objectives like high quality meat to be achieved and might be a better feeding for sustainable aquaculture practices.

\section{References:-}

1. Afser, M. R and Ali, F. 1981. Comparative study of body composition and caloric value of some air breathing fishes. The Indian Journal of Zoology. XXII (2): 81-85.

2. Afser, M. R. 1992. Observation on caloric value and moisture content of some freshwater fishes. Indian Journal of fisheries 4(2): 108-110.

3. Ahmed, I. 2011. Effect of dietary niacin on growth and body composition of two Indian major carps rohu, Labeo rohita, and mrigala, Cirrhinus mrigala (Hamilton), fingerlings based on dose-response study. Aquacult Int. 19: 567-584.

4. Albrektsen, S. Mudheim, $\mathbf{H}$ and Aksnes, A. 2006. Growth, feed efficiency, digestibility and nutrient distribution on Atlantic cad (Gadus morhuo) fed two different fish meal qualities as three dietary levels of vegetable protein sources. Aquaculture, 261: 626-640.

5. Ali, M., A. Nicieza and R.J. Wootton. 2003. Compensatory growth in fishes: a response to growth depression. Fish and Fisheries. 4:147-190.

6. Ali, M . Md, Asif, Ad., Shabuj, Md., Vaumik, S., Zafar, Md., Sharif, B.M. 2016. Status of polyculture pangasius hypophthalmus with Carps in Jhikargacha Upazila of Jessore District, Bangladesh. International Journal of Fisheries and Aquatic Studies, 4(1): 423-430.

7. AOAC, 1995. Official Methods of Analysis (16 ${ }^{\text {th }}$ Ed.) Association of Official Analytical Chemist. Arlington, VA., 125-878. 
8. APHA, 1998. Standard Methods for the Examination of Water and Waste water. 20th ed. American Public Health Association, Washington, DC.

9. Asdari R., Aliyu-Paiko M., Hashim R., Ramachandran S. 2011. Effects of different dietary lipid sources in the diet for Pangasius hypophthalmus (Sauvage, 1878) juvenile on growth performance, nutrient utilization, body indices and muscle and liver fatty acid composition. Aquacult. Nutr. 17, 44-53.

10. Boberg, M. 1990. Clinical effects of fish oil. Narings one word forsking 34: 133-134.

11. Dawson A. S. and Grimm A. S., 1980. Quantitative seasonal changes in the protein, lipid and energy contents of carass, ovaries and liver of adult female Plaice (Pleuronectes platena L). J. Fish Biol., 16, 493495.

12. De Silva, S. S and Gunasekara, R. M. 1989. Effects of dietary protein level and amount of plant ingredients (Phaseolus aureus) incorporated into diets on consumption of growth performance and caracass composition in Oreochromis mloticus (L) fry. Aquaculture 80: 121-133.

13. Dempson I. B., Schwarz C. J., Shears M. and Furey G., 2004. Comparative proximate body composition of Atlantic salmon with emphasis on parr from fluvial and lacustrine habitats. J. Fish Biol., 64, 1257-1271.

14. Diana, J. S., C. K. Lin and K. Jaiyen. 1994. Supplemental feeding of tilapia in fertilized ponds. J. World Aquacult. Soc., 25(4): 497-506.

15. Gopakumar, K. 2003. Indian Aquaculture. Jour. Of Aquaculture 13(1/2): 1-10.

16. Grayton B. D. and Beamish F. W. H., 1997. Effects of feeding frequency on food intake growth and body composition of rainbow trout (Salmo gairdneri). Aquaculture, 11, 159-172.

17. Green, B. W. 1992. Substitution of organic manure for pelleted feed in tilapia production. Aquaculture, 101(3/4): 213-222.

18. Hasan, M. R. and D. J. Macintosh. 1993. Effect of environmental temperature and feeding rate on the growth, feed utilization, and body composition of common carp (Cyprinus carpio L) fry. In Fish nutrition in practice: $4^{\text {th }}$ International symposium on Fish Nutrition and Feeding. 767-778.

19. Hassan, M 1996. Influence of pond fertilization with broiler droppings on the growth performance and meat quality of major carps. Ph. D. Thesis. Deptt. Zool. Fish., Univ. Agri., Faiasalabad. 195 pp.

20. Hassan, M., M. Javed and G. Mahmood. 2000. Response of different levels of nitrogen from broiler droppings towards planktonic biota of major carps rearing ponds. Pakistan J. Biol. Sci., 3(10): 1712-1715.

21. Hepher, B. 1963. Ten years of the research of fish pond fertilization in Israel. ii- Fertilization dose and frequency of fertilization. Bamidgeh, 15: 78-92.

22. Javed, M., A. N. Sheri and S. Hayat. 1995. Influence of pond fertilization and feed supplementation on the planktonic productivity of fish ponds. Pakistan Vet. J., 15: 121-126.

23. Jena, J. K., S. Ayyappan, P. K. Aravindakshan, B. Dash, S. K. Singh and H. K. Muduli. 1998. Comparative evaluation of growth and survival of Indian major carps rearing fingerlings. J. Aquqcult. Trop., 13(2): 143-149.

24. Jhingran, V.G. 1997. Fish and Fisheries of India, $3^{\text {rd }}$ Ed. Hindustan Publishing Corporation, Delhi, India, pp.727.

25. Jonsson N. and Jonsson B., 1998. Body composition and energy allocation in life history stages of brown trout. J. Fish Biol., 53, 13-15.

26. Keshavanath, P., Shivanna and B. Gangadhara, 2006. Evaluation of sugarcane by-product pressmud as a manure in carp culture. Bioresour. Technol., 97: 628-634

27. Khan, M.A. and S. F. Abidi. 2010. Optimum ration level for better growth, conversion efficiencies and body composition of fingerling Heteropneustes fossilis (Baloch). Aquaculture International. 18: 175-188.

28. Krishna, P. V. 2006. Growth performance of advanced fry of Indian major carps catla, rohu in response to different oil cakes. Aquacult, 7(1): 93-97.

29. Krishna, P. V., N. Rama Rao, A. V. V. S. Swami and S. V. Sharma. 2009. Probiotics use in biological systems- A Review. J. Pharm. Tech and Res 1(1): 1-16.

30. Krishna. P.V, Gopi. G , Hemanth Kumar. V and K. Bhanu Prakash. 2015. Comparative study of meat composition of Catla catla, Labeo rohita, Cirrhinus mrigala and Pangasius hypophthalmus under different treatments, International Journal of Advanced Research, 3(10), 480 - 485.

31. Kumar, R., Mukherjee, S. C. Mukherjee, K. P. Prasad and Pal, A. K. 2006. Evalution of Bacillus subtitis as a probiotic to Indian major carp, Labeo rohita. Aquacult. Res. 37: 1215-1221.

32. Lopamudra , B., Keshari , R. S., Kumar , T.R., Kumar, D.B. and Debamita, J. 2015. Impact of Sewage on Certain Biochemical Profiles of Indian Major Carp, Labeo rohita (Hamilton ) 4(8) : 33-39.

33. Murthy, H. S and A. T. R. Naik. 2000. Effect of dietary protein and lipid levels on growth, survival, and food conversion of Indian major carp (Catla catla). Isr. J. Aquac-Bamidgeh., 52(2): 70-76. 
34. Noor Khan, Naureen A. Qureshi1, Grant W. Vandenberg, Pallab K. Sarker, Muhammad., Ashraf, Fayyaz Rasool, Iftikhar A. Qureshi1 and Khalid J. Iqbal1. 2011. Comparative growth performance and body composition of Indian major carps (Catla catla, Cirrhinus mrigala and Labeo rohita) fingerlings when fed an artificial feed under monoculture production. International Journal of Cell \& Molecular Biology (IJCMB). Vol. 2 (3), pp 689-700.

35. Papoutsoglou, S. E and Papaparaskeva-papoutsoglou, E. G. 1978. Comparative studies on body composition of rainbow trout (Salmo gairdneri, R) in relation to type of diet and growth. Aquculture 13: 235243.

36. Peyami, F. Y., Afser, M. R. Nisar, S. K and Anis A. B., Choudhary, 2006. Body composition and caloric value of a teleostean fish, Etropiichthys Vacha (Ham.). Aquculture 7(1): 111-116.

37. Rath, R.K., 2000. Freshwater Aquaculture, 2nd edition, p: 421. Scientific Publishers, Jodhpur, India

38. Razvi, M., 2006. Lahore-Absolutely Fishy: Nutritional Value, pp: 12-13. The Review, Dawn, Lahore, Pakistan.

39. Salam A and Davies P. M. C., 1994. Body composition of Northern Pike (Esox lucius L.) in relation to body size and condition factor. J. Fish Res., 19, 193-204.

40. Schwarz, F. J., Zeitler, M. H and Kirchgessner, M. 1984. Ansatz and verwerting von protein bei karpfen (Cyprinus carpio. L) mit underschi-edlicher proteinus wnwetiw weaefunf. Archieves Tieren'ahr, Berlin 34: 165-178.

41. Shearer K. D., 1984. Changes in the elemental composition of hatchery reared rainbow trout (Salmo gairdneri) associated with growth and reproduction. Can. J. Fish. Aqua. Sci., 41, 1592-1600.

42. Stickney, R. R and Hardy, R. W. 1989. Lipid requirement of some warm water species. Aquaculture 79: 145-156.

43. Ullah, S., Hasan, Z., Zuberi, A., Younus, N., and Rauf, S. 2014 Comparative Study on Body Composition of Two Chinese Carps, Common Carp (Cyprinus carpio) and Silver Carp ( Hypopphalmichthys molitrix) Global Veternaria $13(5)$ : 867-876.

44. Yaakob, W. A. A., and Ali, A. B. 1992. Simple method for backyard production of snake head ( Channa striata Bloch ) fry. Naga, 15:2: 22-23.

45. Zhu, X., S. Xie, W. Lei, Y. Cui, Y. Yang and R.J. Wootton. 2005. Compensatory growth in The Chinese longsnout catfish, Leiocassis longirostris following feed deprivation: Temporal patterns in growth, nutrient deposition, feed intake and body composition. Aquaculture . 248:307-314. 